| GOSOS | Gaziosmanpaşa Üniversitesi Sosyal Bilimler Araştırmaları Dergisi/GOSOS

Gaziosmanpasa University Social Sciences Researches Journal

(Yaz 2015) 10/1: 151-166/(Summer 2015) 10/1: 151-166

\title{
Kırsal Kadınların Girişimcilik Özellikleri ve Girişimciliği Etkileyen Faktörlerin Logit Analizi İle Değerlendirilmesi (Hatay İli Araştırması)
}

\section{Nuray Kızılaslan'1, Miyase Karaömer²}

\begin{abstract}
Bu araştırmada; Hatay İli kırsalındaki kadınlarn girişimcilik özellikleri ve girişimcilik rollerini etkileyen faktörler araştırılmıştır. Araştırma Hatay İli Merkez ve İlçelerine bağhl toplam 21 köyde ve belediyelerde yaşayan 120 kırsal kadını kapsamaktadır. Araştırmada kullanilan veriler anket tekniği ile elde edilmiştir. Analiz aşamasında ise Lojistik Regresyon kullanılmıştır. Araştırmaya katılan kadınların girişimciliğini etkileyen faktörleri bulmak amacıyla yapılan Lojistik Regresyon analizinde kadınlarn girişimcilik eğilimi gösterip göstermemeleri bağıml değişken olarak alınmıştır. Söz konusu bağımlı değişkeni etkileyen bağımsız değişkenler ise medeni durum, sosyal güvence türü, daha önce bir işte çalışma durumu ve şimdiki iş durumudur. Bu bağımsız değiş̧enlerin kadınların girişimcilik eğilimi gösterme olasıllğın artırdığı saptanmıştır. Kadınlar, girişimcilik özelliklerini; risk alabilme, karar verme yeteneği, çalışkanlık ve insanlarla iyi iletişim kurabilme olarak ifade etmişlerdir. Kadınlarn girişim yapmalarn konusunda desteklemek ve bunu hayatın her alanına cinsiyet eşitliği olarak yaymak gerekmektedir. Kadın girişimciliği, siyasi, sosyal, ekonomik ve kültürel anlamda gelişimi ve dönüşümü sağlayacak önemli noktalardan biridir.
\end{abstract}

$\ddot{O} z$

Anahtar Kelimeler: Girişimcilik, Kırsal Kadın, Girişimcilik Eğilimi, Binary Logit Analizi, Hatay.

\section{Rural Women's Entrepreneurship Characteristics and Evaluation of Factors Affecting Entrepreneurship with Logit Analysis (Hatay Province Research)} Abstract
$\begin{aligned} & \text { The data were obtained via questionnaires. For the analysis of the data Logistic Regression } \\ & \text { were used. The women's entrepreneurship tendency was taken as the dependent variable in } \\ & \text { the Logistic Regression Analysis to find the factors affecting the entrepreneurship of the }\end{aligned}$

In this research, factors affecting the entrepreneurial characteristics and entrepreneurial roles of women were investigated in rural areas of Hatay Province. The survey included 120 rural women living in 21 villages of Central District and some other districts of Hatay Province.

\footnotetext{
${ }^{1}$ Prof.Dr. Gaziosmanpaşa Üni. Ziraat Fak. Tarım Ekonomisi Böl. Tokat. Sorumlu Yazar, e-mail: nuray.kizilaslan@gop.edu.tr

${ }^{2}$ Yüksek Lisans Öğrencisi. Gaziosmanpaşa Üni. Ziraat Fak. Tarım Ekonomisi Böl. Tokat
} 


\title{
| Kırsal Kadınların Girişimcilik Özellikleri ve Girişimciliği Etkileyen Faktörlerin Logit Analizi İle Değerlendirilmesi (Hatay İli Araştırması)
}

\begin{abstract}
women who participated in the study. The independent variables were marital status, type of social security, any previous job status and present job status. It was determined that these independent variables increase the possibility of women's showing entrepreneurship tendency. The women stated that entrepreneurial characteristics to take risks, the ability to make decision, diligence and effective communication skills with people. Women should be encouraged to attempt and spread as gender equality in all areas of life. Women entrepreneurship is one of the key points that will provide development and transformation in the political, social, economic and cultural lifes.
\end{abstract}

Keywords: Entreprneurship, Rural Women, Tendency Entreprneurship, Binary Logit Analysis, Hatay.

\section{GİRIŞ}

Girişimcilik sürdürülebilir kalkınmanın sağlanmasında önemli araçlardan birisidir. Girişimcilik eksik istihdam, işsizlik, gelir dağılımdaki adaletsizlik, sosyal refahın arttırılması gibi önemli konularda ülkelerin ekonomik büyümelerine katkı sağlamaktadır. Bu konular ekonomik krizlerle anlaşılmaya başlamış piyasaların serbestleşmesi ile birlikte özel girişimcilik faaliyetleri artmıştır.

Girişimcilik her şeyden önce bir zihniyettir. Bir kişinin bağımsız olarak ya da bir organizasyon içinde, bir fırsatı saptama ve yeni değer yaratmak ya da ekonomik başarı elde etmek için bu fırsatın üzerine gitme motivasyonunu ve kapasitesini tanımlar (Hyrsky, 2001). Girişimci, risk alarak yenilik veya geliştirme yapan kişidir. Diğer bir deyişle, girişimci fırsatları gözleyen ve onları bulduğunda her tür riski alarak fikrini gerçekleştirmeye çalışandır (Schramm, 2005).

Kadın girişimci ise, piyasa ekonomisi içinde kendi işinin sahibi olan, tek başına çalışan ya da yanında işçi çalıştıran, mal veya hizmet üretip satan, kredi kaynaklarını araştıran, işle ilgili acil problemlerin üstesinden gelebilen, yeni koşullara adapte olabilen ve alanında deneyim sahibi olmaya çalışan kadın olarak tanımlamıştır (Dhillon, 1993).

Geçmişten bugüne erkeğin yanında kadının da emeğinin kullanıldığını toplumların kalkınmasında çoğu zaman görünmez emekçiler olarak yerlerini aldıkları görülmektedir. Kadın girişimciliğinin desteklenmesiyle kadınlar toplumda ekonomik aktörler olarak yerlerini almakta görünür emekçiler olarak statü değiştirmektedirler.

Girişimcilerin temel özelliklerinin belirlenmesi konusunda değişik yazarlar tarafından yazılan özellikler Çizelge 1'de derlenmiştir (Arıkan, 2002). 
Çizelge 1. Girişimcilerin Temel Özellikleri

\begin{tabular}{|c|c|c|}
\hline Tarih & Yazar & Özellikler \\
\hline 1848 & Mill & Risk alma \\
\hline 1917 & Weber & Biçimsel otoritenin kaynağı olma \\
\hline 1934 & Schumpeter & Yenilik, önayak olma \\
\hline 1954 & Sutton & Sorumluluğa istek duyma \\
\hline 1959 & Hartman & Biçimsel otoritenin kaynağı olma \\
\hline 1961 & McClelland & Risk alma, başarı güdüsü \\
\hline 1963 & Davids & Hırslı olma, başarı isteği, sorumluluk \\
\hline 1964 & Pickle & İnsan ilişkileri, iletişim becerisi, teknik bilgi \\
\hline 1964 & Litzinger & Riski tercih etme, bağımsızlık, tanınma, liderlik \\
\hline 1965 & Schrage & Doğru algilama,güç \\
\hline 1971 & Palmer Risk ölçme & Risk ölçme \\
\hline 1971 & Homadey & $\begin{array}{l}\text { Başarı güdüsü, özerklik, saldırganlık, güç, } \\
\text { tanınma }\end{array}$ \\
\hline 1973 & Winter & Güç ihtiyacı \\
\hline 1974 & Borland & İçsel güç odağ1 \\
\hline 1974 & Liles & Başarı ihtiyacı \\
\hline 1977 & Gasse & Kişisel değerlere dönüklük \\
\hline 1978 & Timmons & $\begin{array}{l}\text { Güdü, özgüven, amaca dönüklük, orta düzeyde } \\
\text { risk alma, kontrol odağı, yaratıcılık }\end{array}$ \\
\hline 1980 & $\begin{array}{c}\text { Brockhaus Risk üstlenme } \\
\text { eğilimi }\end{array}$ & Risk üstlenme eğilimi \\
\hline 1980 & Sexton Enerjik olma,hırs & Enerjik olma,hirs \\
\hline 1981 & Mescon Montanari & $\begin{array}{c}\text { Başarı, hakimiyet, özerklik, dayanma gücü, } \\
\text { kontrol }\end{array}$ \\
\hline 1982 & $\begin{array}{c}\text { Dunkelbeoungrg,Cooper } \\
\text { Welsh Young }\end{array}$ & $\begin{array}{l}\text { Büyümeye dönüklük,bağımsızlığa dönüklük, } \\
\text { zanaatkarlığa dönüklük, kontrol kaynağı, öz } \\
\text { güven, yenilikçilik. }\end{array}$ \\
\hline
\end{tabular}

Kaynak: (Arıkan, 2002).

Çizelge 1'de de görüldüğü gibi tüm yazarların ortak olarak üzerinde durduğu; pazarda var olan mevcut fırsatları yakalayarak değerlendirebilme ve bir iş fikrine 
dönüştürebilme, risk alma, yenilikçi ve yaratıcı olma, başarı güdüsü gibi özellikler temel oluşturmaktadır.

Kadın girişimcilerin özellikleri bir çalışmada şu şekilde sıralanmıştır (Jalbert, 1999).

- Cesurluk eğilimi

-Yüksek enerji seviyesi

- Kişisel güdüler

- Evli ve ilk çocuk olma

-Sosyal beceriklilik

- Finansal rekabet

-Kişisel ve genel yönetim becerileri

Türkiye' de yürütülen bir çalışmada (Gülçubuk ve ark., 2011), girişimciliğin en temel özelliği cesur olmak, iş takibi ve risk almak olarak sıralanmıştır.

Türk toplumunda kadınlar çoğunlukla ailesiyle yaşayan ve yine tüm gücünü, potansiyelini ailesi için kullanan bireylerdir. Girişimci kadın "güçlü ve güçlendirilmiş” özelliklerinin farkına vardırılması ve ortaya çıkarılmasıyla ekonomik aktörler içerisinde yerini alacaktır. Toplumsal cinsiyet ayrımcılığının ve diğer sosyal sorunların çözümünde kadınların ekonomik yaşamda yer almaları gerekmektedir.

Kadınların girişimcilik özellikleri ve toplumsal yapıları dikkate alınarak kırsal alanda yaşayan kadınların girişimcilik rolleri, özellikleri ve düşüncelerinin belirlenmesinin önemli olduğu yargısına ulaşılarak araştırma konusu seçilmiştir. Seçilen araştırmada; kırsalda yaşayan kadınların girişimcilik özelliklerinin neler olduğu ve girişimcilik eğilimlerinin hangi faktörler tarafından etkilendiği araştırılmıştır.

\section{Materyal ve Yöntem}

$\mathrm{Bu}$ araştırmanın ana materyalini Hatay ili köylerinde ve beldelerde yaşayan kadınlarla yapılan anket çalışmalarıdır.

Hatay'da toplamda 426 köy ve belediyelik bulunmaktadır. Bu köylerin yüzde beşi olan 21 köyle 120 adet anket çalışması yapılmıştır. Söz konusu bu 120 anket sayısı, gayeli olarak belirlenmiştir.Bu rakamlar, TÜİK 2000 Adrese Dayalı Nüfus Kayıt Sistemi verilerinden yararlanılarak belirlenmiş ve İki Aşamalı Tabakalı Rastgele Örnekleme Yöntemi kullanılarak her köyden veya belediyeden anket yapılacak kişi sayısı belirlenmiştir (Düzgüneş ve Ark., 1983, Çıngı 1990). Ayrıca seçilen bu köyler Hatay ili 
ilçelerine homojen şekilde dağıtılmıştır. Seçilen köylerin ait olduğu ilçeler Hatay ilinin coğrafi farklılıkları göz önüne alınarak seçilmiştir. Elde edilen veriler çizelge haline getirilmiştir. Verilerin analizinde Binary Lojistik Regresyon Analizi yapılmıştır (Gujarati, 2008). Bu analiz, kadınların girişimcilik eğilimlerine etkili olan faktörleri belirlemek amacı ile yapılmıştır.

\section{Araştırma Bulguları}

\subsection{Kırsal Kadınlara Göre Girişimcide Olması Gereken Özellikler}

$\mathrm{Bu}$ araştırmada herhangi bir ürün satan ve satış işlemini yaparken kendi adlarına veya ortak olarak bir işyerleri bulunmasa da kendi paralarını kazanan kadınların girişimcilik eğilimi gösterdikleri kabul edilmiştir. İşletme kurarak para kazanan kadınlar ise büyük sermayelerle kurulmuş işletmeleri olmamasına karşılık belediye izinli pazar yerleri veya belediye ruhsatlı işletmeleri olması durumunda, kendi adlarına iş yeri sahibi oldukları için ve bu işletmelerin bütün sorumluluklarını üstlendikleri ve kendi paralarını kazandıkları için girişimci kabul edilmişlerdir. Söz konusu bu araştırmada herhangi bir ürün satarak para kazanma eğilimde olan veya kendi iş yeri olan kadın sayısı $62^{\prime}$ dir. Bunların içinde kendi adına iş yeri olan kadın sayısı ise 7'dir. Hiçbir şekilde kendi parasını kazanma eğilimi olmayan kadınların sayısı ise 58'dir. Bu kadınlar girişimcilik eğilimi göstermemiş kabul edilmektedir. Bu araştırmada kendi paralarını kazanma çabası içinde olan kadınlar görüşülen kadınların $\% 51,67$ 'sini oluşturmuştur.

Kadınlara girişimci olarak nitelendirilen bir kişinin ne gibi özelliklere sahip olması gerektiği sorulmuş ve bazı faktörler Çizelge 2 ' de verilmiştir.

\section{Çizelge 2. Girişimcide Olması Gereken Bazı Özellikler}

\begin{tabular}{|c|c|c|c|c|c|c|c|c|c|c|c|c|}
\hline \multirow{2}{*}{$\begin{array}{l}\text { Girişim } \\
\text { ci } \\
\text { özellikl } \\
\text { eri }\end{array}$} & \multicolumn{6}{|c|}{$\begin{array}{c}\text { Girişimcilik eğilimi gösteren } \\
\text { kadınlar (\%) }\end{array}$} & \multicolumn{6}{|c|}{$\begin{array}{l}\text { Girişimcilik eğilimi göstermeyen } \\
\text { kadınlar }(\%)\end{array}$} \\
\hline & $\begin{array}{l}? \\
\frac{O}{\lambda} \\
\tilde{N}\end{array}$ & R & $\mathrm{N}$ & $\frac{T}{N}$ & $\begin{array}{l}\vec{D} \\
\stackrel{2}{N}\end{array}$ & 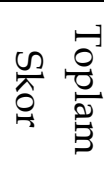 & $\begin{array}{l}? \\
\frac{0}{\pi} \\
\stackrel{n}{N}\end{array}$ & R & 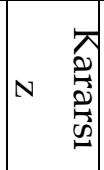 & $\frac{T}{N}$ & 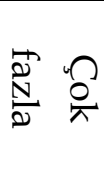 & 足 \\
\hline $\begin{array}{l}\text { Eğitiml } \\
\text { i olmak }\end{array}$ & $\begin{array}{c}17,7 \\
5\end{array}$ & 1,61 & $\begin{array}{c}0,0 \\
0\end{array}$ & $\begin{array}{c}37,1 \\
0\end{array}$ & $\begin{array}{c}43,5 \\
4\end{array}$ & $\begin{array}{c}387 \\
07\end{array}$ & 12,0 & 5,17 & $\begin{array}{c}3,4 \\
4\end{array}$ & $\begin{array}{c}17,2 \\
5\end{array}$ & $\begin{array}{c}62,0 \\
5\end{array}$ & $\begin{array}{c}412, \\
00\end{array}$ \\
\hline $\begin{array}{l}\text { Karar } \\
\text { verme }\end{array}$ & 0,00 & 0,00 & $\begin{array}{c}0,0 \\
0\end{array}$ & $\begin{array}{c}48,3 \\
8\end{array}$ & $\begin{array}{c}51,6 \\
2\end{array}$ & $\begin{array}{c}451, \\
62\end{array}$ & 0,00 & 1,73 & $\begin{array}{c}6,9 \\
0\end{array}$ & $\begin{array}{c}50,0 \\
0\end{array}$ & $\begin{array}{c}41,3 \\
7\end{array}$ & $\begin{array}{c}431, \\
01\end{array}$ \\
\hline
\end{tabular}




\begin{tabular}{|c|c|c|c|c|c|c|c|c|c|c|c|c|}
\hline $\begin{array}{l}\text { yeteneğ } \\
\text { i }\end{array}$ & & & & & & & & & & & & \\
\hline $\begin{array}{l}\text { Lider } \\
\text { özelliği } \\
\text { taşımak }\end{array}$ & 1,61 & 1,61 & $\begin{array}{c}8,0 \\
6\end{array}$ & $\begin{array}{c}46,7 \\
8\end{array}$ & $\begin{array}{c}41,9 \\
4\end{array}$ & $\begin{array}{c}425, \\
83\end{array}$ & 3,44 & 3,44 & $\begin{array}{c}8,6 \\
2\end{array}$ & $\begin{array}{c}32,7 \\
7\end{array}$ & $\begin{array}{c}51,7 \\
3\end{array}$ & $\begin{array}{c}425, \\
91\end{array}$ \\
\hline $\begin{array}{l}\text { Çalışka } \\
\text { n } \\
\text { olmak }\end{array}$ & 0,00 & 0,00 & $\begin{array}{c}3,2 \\
2\end{array}$ & $\begin{array}{c}40,3 \\
3\end{array}$ & $\begin{array}{c}56,4 \\
5\end{array}$ & $\begin{array}{c}453 \\
23\end{array}$ & 0,00 & 3,44 & $\begin{array}{c}3,4 \\
4\end{array}$ & $\begin{array}{c}29,3 \\
2\end{array}$ & $\begin{array}{c}63,8 \\
0\end{array}$ & $\begin{array}{c}453, \\
48\end{array}$ \\
\hline $\begin{array}{l}\text { Risk } \\
\text { alabilen } \\
\text { birey }\end{array}$ & 0,00 & 9,68 & $\begin{array}{c}12, \\
9\end{array}$ & $\begin{array}{c}25,8 \\
0\end{array}$ & $\begin{array}{c}51,6 \\
2\end{array}$ & $\begin{array}{c}419, \\
36\end{array}$ & 0,00 & 5,17 & 6,9 & $\begin{array}{c}39,6 \\
6\end{array}$ & $\begin{array}{c}48,2 \\
7\end{array}$ & $\begin{array}{c}431, \\
03\end{array}$ \\
\hline $\begin{array}{l}\text { İyi } \\
\text { iletişim } \\
\text { kurabil } \\
\text { mek }\end{array}$ & 3,22 & 8,06 & $\begin{array}{l}11, \\
29\end{array}$ & $\begin{array}{c}27,4 \\
3\end{array}$ & $\begin{array}{c}50,0 \\
0\end{array}$ & $\begin{array}{c}412, \\
93\end{array}$ & 0,00 & 1,73 & $\begin{array}{c}5,1 \\
7\end{array}$ & $\begin{array}{c}39,6 \\
6\end{array}$ & $\begin{array}{c}53,4 \\
4\end{array}$ & $\begin{array}{c}444, \\
81\end{array}$ \\
\hline $\begin{array}{l}\text { Deneyi } \\
\text { mli } \\
\text { olmak }\end{array}$ & $\begin{array}{c}14,5 \\
4\end{array}$ & $\begin{array}{c}11,2 \\
9\end{array}$ & $\begin{array}{l}11, \\
29\end{array}$ & $\begin{array}{c}29,0 \\
1\end{array}$ & $\begin{array}{c}33,8 \\
7\end{array}$ & $\begin{array}{c}356, \\
38\end{array}$ & $\begin{array}{c}17,2 \\
5\end{array}$ & $\begin{array}{c}17,2 \\
5\end{array}$ & $\begin{array}{c}8,6 \\
2\end{array}$ & $\begin{array}{c}22,4 \\
2\end{array}$ & $\begin{array}{c}34,4 \\
7\end{array}$ & $\begin{array}{c}339, \\
64\end{array}$ \\
\hline $\begin{array}{l}\text { Teknik } \\
\text { bilgiye } \\
\text { sahip } \\
\text { olmak }\end{array}$ & 9,68 & 6,45 & $\begin{array}{c}1,6 \\
1\end{array}$ & $\begin{array}{c}37,1 \\
0\end{array}$ & $\begin{array}{c}45,1 \\
6\end{array}$ & $\begin{array}{c}401, \\
61\end{array}$ & $\begin{array}{c}13,7 \\
9\end{array}$ & $\begin{array}{c}12,0 \\
9\end{array}$ & $\begin{array}{c}8,6 \\
2\end{array}$ & $\begin{array}{c}34,4 \\
7\end{array}$ & $\begin{array}{c}31,0 \\
3\end{array}$ & $\begin{array}{c}356, \\
86\end{array}$ \\
\hline
\end{tabular}

Girişimcilik eğilimi gösteren ve göstermeyen kadınların girişimcide olması gereken özelliklerden en önemli buldukları özellik çalışkan olmaktır.

Girişimcilik eğilimi gösteren kadınlarda çalışkan olma özelliğini sırasıyla, karar verme yeteneği, lider özelliği taşıma ve risk alabilme takip etmektedir. Girişimcilik eğilimi göstermeyen kadınlarda ise, çalışkan olmak özelliğini; iyi iletişim kurabilmek, risk alabilme ve karar verme yeteneği takip etmektedir.

$\mathrm{Bu}$ araştırmada genel anlamda kadınların girişimcide olması gereken özelliklere verilen cevaplar incelendiğinde ön plana çıkan özellikler; çalışkan olma, kendi karar verebilir olması, risk alabilmedir. 
Bir çalışmada kadın girişimci özellikleri; organizasyon becerisi, akıl ve mantığın yanı sıra sezgilerini kullanma, bağımsız çalışma, gelişmiş iletişim beceresi, empati kurma, yorgunluğa dayanıklılık, mali disipline önem verme, akıl alma konusunda çekingen olmama, yeniliklere açık olma, yönetebileceği kadar risk alma, sabırlı olma, azimli ve inatçı olma, işine kendi için değil, ailesi için sahip çıkma, görüş birliğine dayalı karar ve katılımcılık, çatışma yönetimi, bilgi ve beceriyi paylaşma şeklinde belirtilmiştir (Çivici, 2007).

Yetim (2008) bir çalışmasında kadınların mücadeleci, hırslı, evine iş götüren ve kendileri için erişilmesi zor hedefler belirleyen yapıda oldukları bulgularına ulaşmıştır. Kadın girişimcilerin kişisel özellikleri üç kapsamda ele alınmıştır. Bu özelliklerden ilki olan girişimci olmaktan kaynaklanan kişisel özellikler; kendine güven, yaratıcılık, yenilikçilik, risk alma, akılcılık, bağımsızlık ve rekabetçilik olarak sıralanmıştır. Diğer taraftan sosyo kültürel değerlerle ilgili girişimcilik özellikleri ise; çevresinde saygın biri, çevresindeki kaynakları ve ilişkileri iyi değerlendirebilen, koruyan-gözeten, işbirliğine yönelik, akrabalarının ve yakın çevresinin desteğini kazanmış olarak sıralanabilmektedir. Kadın girişimcilerin kişisel özelliklerini ortaya koyma çerçevesinde ele alınan bir diğer özellikler bütünü ise onların cinsiyet rollerinden kaynaklanan özellikler olarak bilinmektedir. Bunlar ise, iyi iletişim kuran, problemleri kolaylıkla çözebilen, hoşgörülü, özverili ve duygusal olarak sıralanabilmekte olduğunu belirtmiştir.

\section{2. İş Yeri Olan Kadınların İşletmeleri İle İlgili Düşünceleri}

Araştırmaya katılan kadınların \% 5,83'ünün kendine ait bir veya ortak olunan bir işletmesi vardır. İşyeri olan kadınların çoğu iş yerlerini kendi sermayeleriyle kurmuştur, ortak edinmemişlerdir. Sadece biri işletmesini ailesi ile birlikte yürütmektedir. Ancak \% 28,57'si bu sermayeyi kişilere borçlanarak elde etmiştir. Kadınlardan ikisinin bijuterisi bulunmaktadır ve diğer beşinin sahip olduğu iş yeri ise mağaza, terzi, şarküteri, fırın ve tuhafiyedir. Çizelge 3'de işletmesi olan kadınların, işyerlerini kurarken karşılaşmış olabilecekleri bazı sorunlar yer almaktadır.

Çizelge 3. İşletme Kurarken Karşılaşılmış Sorunlar

\begin{tabular}{|r|c|c|c|c|c|c|}
\hline \multirow{2}{*}{ Sorunlar } & \multicolumn{5}{|c|}{ Verilen Cevaplar (\%) } & $\begin{array}{c}\text { Cevapla } \\
\text { rın puan } \\
\text { değeri }\end{array}$ \\
\cline { 2 - 5 } & Çok & $\mathrm{Az}$ & Karars & Fazl & Çok & $\mid 157$ \\
\hline
\end{tabular}

| GAZIOSMANPAŞA ÜNIVERSİTESİ SOSYAL BİLIMLER ARAŞTIRMALARI DERGİSİ 


\begin{tabular}{|l|c|c|c|c|c|c|}
\cline { 2 - 6 } & $\mathrm{az}$ & & $\mathrm{z}$ & $\mathrm{a}$ & fazla & \\
\hline $\begin{array}{l}\text { İş kurmak için gerekli hukuki } \\
\text { düzenlemeler hakkında bilgi } \\
\text { eksikliği }\end{array}$ & 71,42 & 0,00 & 0,00 & 0,00 & 28,58 & 2,14 \\
\hline $\begin{array}{l}\text { Sermaye yetersizliği veya kaynak } \\
\text { yokluğu }\end{array}$ & 0,00 & 28,58 & 0,00 & 42,86 & 28,58 & 3,71 \\
\hline $\begin{array}{l}\text { Hangi alanda iş kurmanın karlı } \\
\text { olacağıyla ilgili bilgi ve bilgi } \\
\text { kaynağı ihtiyacı }\end{array}$ & 28,58 & 14,28 & 14,28 & 28,58 & 14,28 & 2,71 \\
\hline $\begin{array}{l}\text { Devletin iş kurmakla ilgili } \\
\text { teşviklerinden, eğitiminden } \\
\text { desteklerinden faydalanabilmek }\end{array}$ & 0,00 & 0,00 & 0,00 & 14,28 & 85,71 & 4,85 \\
\hline $\begin{array}{l}\text { Devletin iş kurmakla ilgili } \\
\text { teşviklerinden, eğitim ve } \\
\text { desteklerinden haberdar } \\
\text { olmamak }\end{array}$ & 0,00 & 0,00 & 0,00 & 42,86 & 57,14 & 4,57 \\
\hline Nitelikli personel bulmak & 71,42 & 14,28 & 0,00 & 14,28 & 0,00 & 1,57 \\
\hline Uygun bir mekân bulmak & 42,86 & 14,28 & 14,28 & 14,28 & 14,28 & 2,42 \\
\hline $\begin{array}{l}\text { Toplumun kadınlar hakkındaki } \\
\text { geleneksel düşüncesi }\end{array}$ & 42,86 & 0,00 & 0,00 & 42,86 & 14,28 & 2,85 \\
\hline $\begin{array}{l}\text { Kurulacak olan işletmenin alanı } \\
\text { veya piyasası ile ilgili bilgi edine } \\
\text { bilme }\end{array}$ & 28,58 & 0,00 & 42,86 & 28,58 & 0,00 & 2,71 \\
\hline Resmi işlemlerin çok olması & 14,28 & 14,28 & 0,00 & 0,00 & 71,48 & 4,00 \\
\hline
\end{tabular}

Kadınlar işletmelerini kurma aşamasında, devletin iş kurmakla ilgili teşviklerinden, eğitiminden desteklerinden faydalanabilmede en fazla sorunu yaşamışlardır. Yine devletin iş kurmakla ilgili teşviklerinden, eğitim ve desteklerinden haberdar olmamak da kadınlar için çok fazla sorun olmuştur. Kadınların en az sorun yaşadıkları durum ise nitelikli personel bulmaktır. Kadınların çok fazla olmasa da, fazla sorun olmuş durumlar ise sermaye bulmak ve resmi işlemlerin çok olmasıdır. 
İşletmesi olan kadınların sahip oldukları işletmelerini açmalarına sebep olacağ düşünülen bazı durumları ne ölçüde önemli buldukları Çizelge 4' de yer almaktadır.

Çizelge 4. İşletme Kurma Nedenleri

\begin{tabular}{|c|c|c|c|c|c|c|}
\hline \multirow[t]{2}{*}{ Nedenler } & \multicolumn{5}{|c|}{ Verilen cevaplar (\%) } & \multirow{2}{*}{$\begin{array}{c}\text { Cevapla } \\
\text { rın puan } \\
\text { değeri }\end{array}$} \\
\hline & $\begin{array}{l}\text { Çok } \\
\text { az }\end{array}$ & $\mathrm{Az}$ & $\begin{array}{c}\text { Karars1 } \\
\mathrm{z}\end{array}$ & Fazla & $\begin{array}{l}\text { Çok } \\
\text { fazla }\end{array}$ & \\
\hline Ekonomik özgürlük & 0,00 & 0,00 & 0,00 & 28,58 & 71,42 & 4,71 \\
\hline Kazanç sağlamak & 0,00 & 0,00 & 14,28 & 14,28 & 71,42 & 4,57 \\
\hline Sosyal statüyü yükseltmek & 14,28 & 0,00 & 0,00 & 28,58 & 57,14 & 4,14 \\
\hline $\begin{array}{l}\text { Aile içinde daha saygın bir } \\
\text { birey olmak }\end{array}$ & 28,58 & 0,00 & 14,28 & 14,28 & 42,86 & 3,42 \\
\hline $\begin{array}{l}\text { Başkasının emri altında } \\
\text { çalışmayı istememek }\end{array}$ & 0,00 & 0,00 & 0,00 & 57,14 & 42,86 & 4,42 \\
\hline $\begin{array}{l}\text { Aileye gelecekte iş imkanı } \\
\text { sağlamak }\end{array}$ & 0,00 & 0,00 & 14,28 & 42,86 & 42,86 & 4,00 \\
\hline $\begin{array}{l}\text { Bir kadının başarısını } \\
\text { kanıtlama }\end{array}$ & 0,00 & 0,00 & 28,58 & 28,58 & 42,86 & 4,71 \\
\hline Yeni bir çevre edinmek & 28,58 & 14,28 & 14,28 & 28,58 & 14,28 & 2,71 \\
\hline İssletmenin ilgi alanına uyması & 28,58 & 0,00 & 42,86 & 28,58 & 0,00 & 2,71 \\
\hline $\begin{array}{l}\text { Kurulan işletmenin karlı bir iş } \\
\text { türü olması }\end{array}$ & 14,28 & 0,00 & 14,28 & 28,58 & 42,86 & 3,85 \\
\hline $\begin{array}{l}\text { Kurulan işletmenin bulunan } \\
\text { yerde ilk olması }\end{array}$ & 42,86 & 14,28 & 0,00 & 14,28 & 28,58 & 2,71 \\
\hline $\begin{array}{l}\text { Alınan eğitimin seviyesinin } \\
\text { yeterli olması }\end{array}$ & 42,86 & 0,00 & 14,28 & 28,58 & 14,28 & 3,28 \\
\hline $\begin{array}{l}\text { Alınan eğitim alanına uygun } \\
\text { olmaması }\end{array}$ & 42,86 & 0,00 & 0,00 & 14,28 & 42,86 & 3,14 \\
\hline $\begin{array}{l}\text { Kurulan işletmenin iflas } \\
\text { riskinin az olması }\end{array}$ & 14,28 & 14,28 & 14,28 & 14,28 & 42,86 & 3,57 \\
\hline
\end{tabular}


Çizelge 4'e bakıldığında işyeri olan kadınlar için, iş kurma nedenleri arasında çok fazla etkili olan unsurlar, ekonomik özgürlük, bir bayanın başarılı olacağını başkalarına kanıtlamak ve kazanç sağlamadır. Fazla etkili olan unsurlar ise toplum içinde saygınlığı arttırmak, sosyal statüyü yükseltmek, başkasının emri altında çalışmayı istememek, kurdukları işletmenin karlı bir iş türü olduğu düşüncesi ve iflas riskinin az olacağı düşüncesi, aileye gelecekte var olması düşünülen bir iş imkanı bırakmak olarak sıralanabilir. Kadınların sahip oldukları işi kurmalarına en az etkili olan neden ise, yeni çevre edinmek, işletmenin ilgi alanına uyması, kurulan işletmenin bulunan yerde ilk olmasıdır.

Çizelge 5'de ise işletmesi olan kadınların kendilerini iş kurmaya iten özellikler arasında olacağı düşünülen bazı unsurlar ve bu unsurların kadınlar için ne derece önemli olduğu verilmiştir.

Çizelge 5. İş Kurmaya İten Kişisel Özellikler

\begin{tabular}{|l|c|c|c|c|c|c|}
\hline \multirow{2}{*}{ Özellikler } & \multicolumn{5}{|c|}{ Verilen cevaplar (\%) } & $\begin{array}{c}\text { Cevapların } \\
\text { puan } \\
\text { değeri }\end{array}$ \\
\cline { 2 - 6 } & Çok az & Az & Karasız & Fazla & $\begin{array}{c}\text { Çok } \\
\text { fazla }\end{array}$ & \\
\hline Eğitimli olmak & 85,71 & 14,28 & 0,00 & 0,00 & 0,00 & 1,14 \\
\hline $\begin{array}{l}\text { Karar verebilen bir birey } \\
\text { olmak }\end{array}$ & 0,00 & 0,00 & 0,00 & 28,58 & 71,42 & 4,71 \\
\hline Lider özelliği taşımak & 0,00 & 0,00 & 0,00 & 28,58 & 71,42 & 4,71 \\
\hline $\begin{array}{l}\text { Risk alabilen bir birey } \\
\text { olmak }\end{array}$ & 0,00 & 42,86 & 0,00 & 28,58 & 28,58 & 3,42 \\
\hline $\begin{array}{l}\text { Çalışkan olmak } \\
\text { İnsanlarla iyi iletişim } \\
\text { kurabilme }\end{array}$ & 14,28 & 0,00 & 0,00 & 57,14 & 28,58 & 3,85 \\
\hline $\begin{array}{l}\text { Kurulmuş iş alanında } \\
\text { deneyimli olmak }\end{array}$ & 14,28 & 0,00 & 14,28 & 14,28 & 57,14 & 4,00 \\
\hline $\begin{array}{l}\text { İş alanının piyasası ile } \\
\text { ilgili teknik bilgiye sahip } \\
\text { olmak }\end{array}$ & 28,58 & 0,00 & 28,58 & 28,58 & 14,28 & 3,00 \\
\hline
\end{tabular}


Çizelge 5'deki verilere göre, kadınların, kendi işine sahip olmayı istemelerindeki kişisel özelliklerinden en fazla etkili olan unsurlar, çalışkan olmak, liderlik özelliği taşıyabilmek ve kendi kararlarını alan bir birey olmaktır. En az etkili bulunan özellik ise eğitimli olmaktır. Ayrıca kadınlar insanlarla iyi iletişim kuran bir birey olmayı, kurdukları iş ile ilgili deneyimli olmayı da fazla önemli bir özellik olarak görmektedir, denilebilir.

İşyeri olan kadınlara işyerlerini kurduktan sonra karşılaşmış olabilecekleri sorunların ne ölçüde sorun olduğu incelendiğinde, kadınlar işlerini kurduktan sonra en az sorunu iş ile ilgili olan kişilerden (müşteri ve ticari ilişkisi olan kişi veya kurumlar) farklı davranışlar görmede yaşamıştır. En fazla sorun ise başarısız olma korkusu ve toplumun kalıplaşmış düşüncelerinde yaşamıştır. Kadınlar, hem işletmeleri ile ilgili hem de evdeki sorumluluklarını yerine getirebilmede ve iş konusunda tecrübelerinin olmayışında fazla sorun yaşamıştır. İşletmenin sürekliliğini koruyabilme kaygısı ise kadınlar için bir sorun olmaya devam etmektedir.

Ayrıca anket çalışması yapılan kadınlara kollektif, komandit, limitet şirket kavramlarını bilip bilmedikleri de sorulmuştur. Kadınların 106'sı bu şirket isimlerini hiç duymamışken 14'ü duyduklarını söylemiştir. Ne olduğunu bildiklerini söyleyen kadınlardan bu şirketleri tanımlamaları istendiğinde, ayrı ayrı tanımlayamasalar da genel olarak bu şirketlerin 'ortaklarla kurulmuş şirketler' veya 'büyük şirketler' olduklarını söylemektedirler. Kadınların bu şirketleri tam tanımlayamasalar da ne oldukları hakkındaki fikirleri yanlış denilemez niteliktedir.

Son olarak kadınlara gerekli imkanlara sahip (sermaye, eğitim, tecrübe) olan ve bir iş kurmak isteyen bayanlara tavsiye(ler)iniz nelerdir sorusu yöneltilmiştir. Cevap olarak toplumun eleştirilerini önemsemeyip, kendine güvenip düşündüğü işi yapmalıdır sözlerine benzer cümleler kurmaktadırlar. Buradan da kadınların toplumsal eleştirilerin her iş kuracak kadına yöneltilebileceği düşüncesinde oldukları ancak bu kaygıdan uzaklaşmaları gerektiği konusunda öneriler sunmuşlardır.

Ayrıca eğer bir bayan iş kurmak için fırsat ve imkanlara sahip değilse, ona bulunabileceğiniz tavsiye(ler)iniz nelerdir sorusu da sorulmuştur. Bu soruya verilen cevaplar ise, vazgeçmesin, denesin veya eğitim alsın şekillerinde olmaktadır. 
3.3. Kırsal Kadınların Girişimciliklerini Etkileyen Faktörlere Yönelik Lojistik Regresyon Analizi Sonuçları

Söz konusu bu analiz Hatay ili kırsalındaki kadınların girişimciliği etkileyen faktörleri ortaya koyma amacıyla yapılmıştır. Tahmin edilen modelde girişimcilik eğilimi gösteren kadınlara 1 göstermeyen kadınlara 0 kodu verilmiş ve kadınların girişimcilik eğilimi gösterme durumu bağımlı değişken olarak alınmıştır. Bağımsız değişkenler ise, yaş eğitim seviyesi, medeni durum, şimdiki çalışma durumu, daha önce çalışma durumu ve sahip olunan sosyal güvence türüdür. Söz konusu bağımsız değişkenler analiz için şu şekilde kodlanmıştır:

Çizelge 6. Lojistik Regresyon Yapılan Değişkenler

\begin{tabular}{|l|l|}
\hline \multicolumn{1}{|c|}{ Değişkenler } & \multicolumn{1}{c|}{ Kodlar } \\
\hline Yaş (YAS) & $\begin{array}{l}\text { 16-25 Yaş aralığı: 1, 26-40 yaş aralığı:2, 41 } \\
\text { ve daha fazla olan yaş:3 }\end{array}$ \\
\hline Eğitim seviyesi (ES) & $\begin{array}{l}\text { Okuryazar olmayan: 1, okuryazar: 2, } \\
\text { ilkokul mezunu: 3, ortaokul mezunu:4, } \\
\text { lise mezunu: 5, üniversite mezunu:6 }\end{array}$ \\
\hline Medeni durum (MD) & Evli:1, bekar: 0 \\
\hline Sosyal güvence türü (SGT) & $\begin{array}{l}\text { SSK:1, BAĞ-KUR:2, Emekli Sandığı:3, } \\
\text { Yeşil Kart uygulaması:4 }\end{array}$ \\
\hline $\begin{array}{l}\text { Daha önce bir işte çalışma durumu } \\
\text { (DOCD) }\end{array}$ & Daha önce çalışma:1, çalışmama:0 \\
\hline Şimdiki iş durumu (SCD) & Bir işte çalışıyor:1, çalışmıyor:0 \\
\hline
\end{tabular}

Söz konusu bağımsız değişkenlere uygulanan Lojistik Regresyon analizinin sonuçları Çizelge 7' de verilmiştir.

Çizelge 7. Lojistik Regresyon Analizi Sonuçları

\begin{tabular}{|l|c|c|c|c|c|}
\hline & $\begin{array}{c}\text { Katsayılar } \\
(\mathrm{B})\end{array}$ & $\begin{array}{c}\text { Standart } \\
\text { hata }\end{array}$ & $\mathrm{Z}$ & $\mathrm{P}$ & Odds oran \\
\hline Yaş &, 063 &, 325 &, 037 &, 847 & 1,065 \\
\hline $\begin{array}{l}\text { Eğitim } \\
\text { seviyesi }\end{array}$ &, 234 &, 268 &, 762 &, 383 & 1,263 \\
\hline Medeni & 1,818 &, 773 & 5,537 &, 019 & 6,162 \\
\hline
\end{tabular}




\begin{tabular}{|l|c|c|c|c|c|}
\hline durum & & & & & \\
\hline $\begin{array}{l}\text { Sosyal } \\
\text { güvence } \\
\text { türü }\end{array}$ & 1,029 &, 225 & 20,911 &, 000 & 2,800 \\
\hline $\begin{array}{l}\text { Daha önce } \\
\text { bir işte } \\
\text { çalışma } \\
\text { durumu }\end{array}$ & 1,017 &, 560 & 3,291 &, 070 & 2,764 \\
\hline $\begin{array}{l}\text { Simdiki } \\
\text { çalışma } \\
\text { durumu }\end{array}$ &,- 119 &, 068 & 3,032 &, 082 &, 888 \\
\hline Sabit say1 & $-3,927$ & 1,814 & 4,687 & 0,30 & 0,20 \\
\hline \multicolumn{2}{|c|}{ LOG likehood square $=0,477$} \\
\end{tabular}

Bu lojistik regresyon analizinde tahmin edilen model şu şekildedir:

$\mathrm{Y}=\beta_{0}+\beta_{1 \mathrm{MD}}+\beta_{2 \mathrm{SGT}}+\beta_{3 \mathrm{DOCD}}+\beta_{4 \mathrm{SCD}}$

Kadınların girişimcilik rollerini belirleme olasılığ regresyon analizi sonuçları Çizelge 8'de görülmektedir. Bu modeldeki bağımsız değişkenlerden, yaş (YAS) ve eğitim seviyesi (ES) istatistiki olarak önemsiz bulunmuştur. Yani bu faktörlerin kadınların girişimcilik rollerini belirlemede herhangi bir ihtimali yoktur.

Öte yandan medeni durum (MD) değişkenin katsayısı $(\mathrm{P}=0,019)$ ile sosyal güvence türü (SGT) değişkeninin katsayısı $(0,000)$ 0,05 önem seviyesinde anlamlı bulunmuştur. Daha önce bir işte çalışma durumu değişkeninin katsayısı (DOCD) $(\mathrm{P}=$ $0,070)$ ve şimdiki çalışma durumu (SCD) değişkeninin katsayısı ise $(P=0,082) \quad 0,10$ anlam düzeyinde anlamlı bulunmuştur. B sütunundaki değerler ilişkinin yönünü göstermektedir. Buna göre girişimcilik eğilimi gösterip göstermeme ile görüşülen kişinin medeni durumu, sahip olunan sosyal güvence türü, daha önce bir işte çalışma durumu bakımından pozitif yönlü bir ilişki bulunurken, görüşülen kişinin şimdiki çalışma durumu bakımından negatif yönlü bir ilişki olduğu görülmektedir.

0, 10 anlam düzeyinde anlamlı bulunan şimdiki çalışma durumunun girişimcilik eğilimi gösterme katsayısı negatif olduğu için odds oranı 1'den küçüktür. 
Yorum yapabilmek için odds oranını 1/odds oranı olarak düzeltmek gereklidir. Diğer değişkenler sabitken şu an herhangi bir işte çalışmayan kadınların çalışan kadınlardan girişimcilik eğilimi gösterme olasılığının 1,12 kat daha fazla olması beklenir. Çalışmaya katılan evli olan kadınların girişimcilik eğilimi gösterme olasılığg 6,16 kat artmaktadır. Buna göre evliler bekarlara göre daha fazla girişimcilik eğilimi göstermektedir denilebilir. Bir diğer bağımsız değişken olan sahip olunan sosyal güvence türünde değişme, araştırmaya katılan kadınların girişimcilik eğilimi gösterme olasılıklarını 2,80 kat artırmaktadır denilebilir. Yine daha önce bir işte çalışma durumunda değişme, kadınların girişimcilik gösterme olasılığını 2,76 kat artırmaktadır denilebilir. Buna göre daha önce herhangi bir işte daha önce çalışmış olan kadınların girişimcilik eğilimi gösterme olasılığı, daha önce bir işte çalışmamış kadınlardan daha fazladır.

Minniti and Arenius, (2003) tarafından, 37 ülkede yapılmış olan araştırmada, kadınların girişimciliğini etkileyen faktörler sırasıyla; demografik çevre ve aile yapısı, okur-yazarlık ve eğitim, sosyoekonomik çevre, işgücü istihdam, cinsiyet ve örgütsel biçimler ve sektörsel istihdam ve ekonomik gelişme olarak belirlenmiştir.

İplik (2012), kadınların başka bir gelire sahip olup olmamalarının girişimci olma kararlarını etkileyen en önemli değişken olduğu, kadının çalışması durumunda aile birliğinin zayıflayacağını, kocasıyla daha az ilgileneceğini, çocuklarına daha az vakit ayıracağını, ailenin sosyal ilişkilerinin zayıflayacağını ve kadının gereğinden fazla yorulacağ1 ve yıpranacağını düşünenlerin daha az girişimci olma eğiliminde oldukları, dağ köylerinde yaşayan kadınların ova köylerinde yaşayan kadınlara göre daha fazla sorunla karşılaştıkları ve dağ köylerindeki bu kadınların uygun materyal temini ve pazarın durgun olması gibi problemlerle daha çok karşılaştıkları tespit edildiğini belirtmiştir.

Araştırmaya katılan kadınların girişimciliklerini etkileyen faktörler göz önüne alındığında, ekonomik düşünce ve işgücü piyasasında yer almanın önemli olduğu görülmektedir. Kadın girişimciliğin artırılması için kadınlara verilecek eğitimlerde uygulamalı çalışma alanlarının yaratılması büyük yarar sağlayabilecektir.

\section{Sonuç ve Öneriler}

Toplumların sosyal değişimine bağlı olarak kadınların da yeni fikirlere açık, bilgi ve yeteneklerini ekonomik kazanca dönüştürmeye eğilimli bir yapı kazanmaya doğru ilerledikleri görülmektedir. Toplumsal yaşamdaki bu ilerleme kadınların 
ekonomik hayatta yer almalarını ve ekonomik kalkınmayı arttırıcı rol üstlenmelerini sağlamaktadır.

$\mathrm{Bu}$ araştırmada kırsal kadınların girişimcilik özellikleri ortaya konulmuştur. Araştırmada kadınların bir iş kurmak istediklerinde önem verdikleri konu, kazanç sağlama şeklinde bulunmuştur. Bir iş yerine sahip olamamada en fazla etkili neden ve sorun olabilecek faktör, sermaye bulmaktır.

Girişimciliği kendi işinin sahibi olan kişi olarak tanımlayan kadınlar için, girişimci bir bireyde en fazla bulunması gereken özellik çalışkan olmak ve kendi karalarını verebilen bir birey olmaktır. Bunun yanı sıra insanlarla iyi iletişim kurmak, eğitimli olmak, lider özelliği taşımak, risk alabilen bir birey olmak, iş alanı ile ilgi teknik bilgiye sahip olmak kadınlar için bir girişimcide olması gereken önemli özelliklerdendir. $\mathrm{Bu}$ sonuçlar kadınların girişimcilik rollerini benimsediğini göstermektedir.

$\mathrm{Bu}$ kadınların işletmelerini kurma aşamasında karşılaşmış olabilecekleri düşünülen bazı sorunlardan, en çok devletin iş kurma ile ilgili teşvik ve eğitimlerden haberdar olma ve faydalanma konusunda sorun yaşamışlardır. En az sorunu ise gerekli niteliklere sahip personel bulmakta yaşamışlardır. İşletmelerini kurduktan sonra ise en fazla sorunu başarısız olma korkusu ve toplumun kalıplaşmış düşüncelerinde yaşamışlardır. Bu konudaki eğitim çalışmalarının daha etkin hale getirilmesi gerekir. İşletme kurma nedenleri arasında ekonomik özgürlük ve bir kadının başarısını kanıtlama duygusu ön planda gelmektedir.

Kadınların girişimciliğinin belirlenmesinde etkili olan faktörleri belirlemek için yapılan Logistik Regresyon analizinde ise; medeni durum, sosyal güvence türü, daha önce bir işte çalışma durumu, şimdiki çalışma durumunun etkili olduğu belirlenmiştir.

Siyasi, sosyal, ekonomik ve kültürel anlamda gelişimi ve dönüşümü sağlayacak önemli noktalardan biri kadınları girişim yapmaları konusunda desteklemek ve bunu hayatın her alanına cinsiyet eşitliği olarak yaymaktır. Kırsal alandaki kadınların girişimcilikle ilgili yayım eğitimleri kapsamında bilgilendirilmesi ve motive edilmesi gerekmektedir.

\section{KAYNAKLAR}

Arıkan, S. (2002), Girişimcilik Temel Kavramlar ve Bazı Güncel Konular, Siyasal Kitabevi, Ankara. 
Çıngı, H. (1990), Örnekleme Kuramı. Hacettepe Üniversitesi Fen Fakültesi Yayınları Ders Kitapları Dizisi: 20. H.Ü. Fen Fakültesi Basımevi. Ankara.

Çivici, Ş. (2007), Türkiye'de Kadın Girişimci. Durum Raporu, Ticaret Odası. Kayseri. http:/www.kayserito.org.tr/web2/media/kadingirisimci_tr.doc.

Erişim Tarihi: (29.03.2014).

Dhillon, P.K. (1993), Women Entrepreneurs, Blaze Publishers and Distributors PVT Ltd., Hirsrich and Brush, Researchers on Entrepreneurship:A Review.

Düzgüneş, O.; Kesici, T.; Gürbüz, F. (1983), İstatistik Metotları 1.Ankara Üniversitesi Ziraat Fakültesi Yayınları:861, Ders Kitabı:229, Ankara.

Gujarati, D. (çev. Ümit Şenesen, Gülay Günlük Şenesen), (2008), Temel Ekonometri, Literatür Yayınları, ISBN 975-7860-99-9.

Gülçubuk, B.; Savc1, İ.; Özer, D.; Demiryürek, K. (2011), Türkiye'de Kırsal Alanda Kadın Girişimciliğini Etkileyen Faktörlerin Belirlenmesi ve Kadınların Bu Konuda Güçlendirilmesine Yönelik Politika Önerilerinin Geliştirilmesi, TÜBİTAK Projesi No: 108K523, Ankara.

Hyrsky, K. (2001), "Relations on The Advent of a More Enterprising Culture In Finland: An Explotary Study", Jyvaskyla Studies, Business and Economics.

İplik, E. (2012), Osmaniye İli Kırsalındaki Kadın Girişimciliği, Doktora Tezi, Çukurova Üniversitesi, Fen Bilimleri Enstitüsü, Tarım Ekonomisi Anabilim Dalı, Adana.

Jalbert S. (1999), The Global Growth of Women Entrepreneurs, Economic Reform Today, CIPE.

Minniti, M. and Arenius, P. (2003), "Women in Entrepreneurship", The Entrepreneurial Advantage Of Nations:First Annual Global Entrepreneurship Symposium, United Nations Headquarters.

Schramm, C. (2005), The Entrepreneuial Society of Tomorrow, University of Rochester Commencement, Kauffmann Foundation Missouri.

Yetim, N. (2008), “Sosyal Sermaye Olarak Kadın Girişimciler: Mersin Örneği”, Mersin Üniversitesi, Fen Edebiyat Fakültesi, Sosyoloji Bölümü, Mersin. 